\title{
Influence of Lap Splices on the Deformation Capacity of RC Walls. I: Database Assembly, Recent Experimental Data, and Findings for Model Development
}

\author{
João P. Almeida ${ }^{1}$; Ovidiu Prodan²; Danilo Tarquini ${ }^{3}$; and Katrin Beyer, M.ASCE ${ }^{4}$
}

\begin{abstract}
Recent postearthquake missions have shown that reinforced concrete (RC) wall buildings can experience critical damage owing to lap splices, which led to a recent surge in experimental tests of walls with such constructional details. Most of the 16 wall tests described in the literature thus far were carried out in the last six years. This paper presents a database with these wall tests, including the description of a new test on a wall with lap splices and a corresponding reference wall with continuous reinforcement. They complement the existing tests by investigating a spliced member with a shear span ratio smaller than two, which is the smallest among them. The objective of this database is to collect information not just on the force capacity but mainly on the deformation capacity of lap splices in reinforced concrete walls. It is shown that (1) well-confined lap splices relocate the plastic hinge above the lap splice, (2) lap splices with adequate lengths but insufficiently confined attain the peak force but their deformation capacity is significantly reduced, and (3) short and not well-confined lap splices fail before reaching the strength capacity. The analysis of the test results, which are used in the companion paper for the finite element analysis of walls with lap splices, indicates in particular that the confining reinforcement ratio and the ratio of shear span to lap splice length influence the lap splice strain capacity. DOI: 10.1061/(ASCE)ST.1943-541X.0001853. (C) 2017 American Society of Civil Engineers.
\end{abstract}

Author keywords: Reinforced concrete (RC) walls; Lap splices; Database; Experimental tests.

\section{Introduction}

The transfer of forces between lap-spliced rebars relies fundamentally on the inherently brittle mechanism of concrete-steel bond. Although the common practice for the design of bridges is to avoid lap splices within plastic hinges, in reinforced concrete (RC) building walls, longitudinal rebars are typically spliced at the base of the member where stresses and strains are largest (Hardisty et al. 2015; Lowes et al. 2012). To avoid brittle failures, current standards impose limits on the reinforcement percentage that can be spliced as a function of the ductility category of the plastic region [NZS 3101-Part 1 (Standards New Zealand 2006)], promote the location of splices away from high tensile stress regions

${ }^{1}$ Research Associate, Earthquake Engineering and Structural Dynamics Laboratory, School of Architecture, Civil and Environmental Engineering, École Polytechnique Fédérale de Lausanne, EPFL ENAC IIC EESD, GC B2 484, Station 18, CH-1015 Lausanne, Switzerland (corresponding author). E-mail: joao.almeida@epfl.ch

${ }^{2}$ Assistant Professor, Faculty of Civil Engineering, Technical Univ. of Cluj-Napoca, 15 C Daicoviciu St., RO-400020, Cluj-Napoca, Romania. E-mail: ovidiu.prodan@mecon.utcluj.ro

${ }^{3} \mathrm{Ph} . \mathrm{D}$. Candidate, Earthquake Engineering and Structural Dynamics Laboratory, School of Architecture, Civil and Environmental Engineering, École Polytechnique Fédérale de Lausanne, EPFL ENAC IIC EESD, GC B2 484, Station 18, CH-1015 Lausanne, Switzerland. E-mail: danilo.tarquini@epfl.ch

${ }^{4}$ Associate Professor, Earthquake Engineering and Structural Dynamics Laboratory, School of Architecture, Civil and Environmental Engineering, École Polytechnique Fédérale de Lausanne, EPFL ENAC IIC EESD, GC B2 484, Station 18, CH-1015 Lausanne, Switzerland. E-mail: katrin.beyer@epfl.ch

Note. This manuscript was submitted on October 3, 2015; approved on March 22, 2017; published online on September 19, 2017. Discussion period open until February 19, 2018; separate discussions must be submitted for individual papers. This paper is part of the Journal of Structural Engineering, (C) ASCE, ISSN 0733-9445.
[ACI 318M-11 (ACI 2011); EN 1992-Part 1-1 (European Committee for Standardization 2004)], or accept lap splices only at the extremity of the plastic region furthest away from the critical section [SIA 262 (SIA 2004)]. Minimum confinement reinforcement for lap splices in regions undergoing plastic deformations is also prescribed [EN 1992-Part 1-1 (European Committee for Standardization 2004); SIA 262 (SIA 2004)]. Walls in buildings constructed before such guidelines were in place have often all their bars spliced at the base, short splice lengths, and unconfined splices.

Performance-based seismic design and assessment requires estimates of the deformation capacity of members undergoing inelastic deformation. Previous research on lap splice performance focused largely on the strength capacity of lap splices (e.g., Orangun et al. 1977; Zuo and Darwin 2000). Experimental research on the deformation capacity of members with lap splices is scarce. Past tests were carried out on RC beams and columns (e.g., Biskinis and Fardis 2010b; Priestley et al. 1996), and on RC walls (e.g., Hannewald 2013). This paper focuses on the latter.

The objective of this paper is threefold: (1) to establish a database of wall tests with lap splices, which collects and systematizes the experimental results on RC walls; (2) to present the results of two new wall tests, one with lap splices and one without, which complement the existing tests by investigating for the first time a spliced member with shear span ratio $L_{s} / h<2$; and (3) to discuss qualitatively and quantitatively on the basis of observations from postearthquake reconnaissance missions and tests the influence of the individual factors previously outlined on the deformation capacity of lap splices.

This paper starts with a review of field and experimental observations on structural elements with lap splices, continues with the presentation of the new experimental results on two RC walls, and finally, based on these field and experimental results, considers the influence of lap splices on the cyclic response of RC walls. The paper concludes with a summary of the factors that have the most significant influence on lap splice displacement ductility. 


\section{Review of Field and Experimental Observations}

The force-transfer mechanism of lap splices involves bond stresses between concrete and rebars. The resultant bond force can be decomposed into a component parallel to the rebar axis and a radial one. The former causes shearing of the concrete between the rebar ribs, whereas the latter radial forces induce tensile stresses in the surrounding concrete (Tepfers 1979). These two components can be directly related with the two types of bond failures that are usually considered, namely pull-out—also described as "crushing and sleeving" (Priestley et al. 1996) — and splitting. If the rebar lugs are spaced far apart, the concrete cover is insufficient, the tensile strength is low, or the confinement provided by the transverse reinforcement does not suffice to keep cracks small, splitting failure will occur. In particular, concrete cover appears to be a critical factor when it is equal to or less than three rebar diameters-although splitting can also take place with larger covers (ACI 2012). Therefore, while anchored bars in foundations or well-confined beamcolumn joints are more likely to sustain pull-out failures, rebars along the height of $\mathrm{RC}$ walls are more susceptible to splitting failure due to the small concrete cover characteristically employed in wall construction. This will be the failure mode assumed throughout the present work. A larger attention from the research community has been given to anchorage and bond-slip relations for anchored bars sustaining pull-out failure rather than splitting failure. For spliced rebars, researchers highlighted the role of transverse ties in enabling a shear friction mechanism to transfer forces from one spliced bar to the other, namely in sustaining a diagonal compression field across the spliced rebars (Paulay 1982). Before splitting cracks form, the bond transfer relies largely on the tensile strength of the concrete whereas the shear friction plays a lesser role. Shear friction is activated after splitting cracks form and the confining reinforcement is subjected to significant tensile strains (Priestley et al. 1996).

The detailing and content of the member reinforcement will determine the orientation of the splitting cracks, and a typical division is often made in terms of side splitting and face splitting. According to ACI (2012), for reinforcing layers with rebar spacing larger than twice the concrete cover, splitting cracks occur perpendicularly to the surface and along the rebar lengths (face splitting). If the cover is larger than twice the bar spacing, cracks will form in the plane of the reinforcing layer (side splitting). Additionally, Orangun et al. (1977) illustrated how face-splitting cracks just before failure will develop either a face-and-side split failure or a $V$-notch failure (i.e., with further inclined cracking to the surface), the latter occurring if the bar spacing is several times larger than the concrete cover. This separation between face and side splitting has been considered in physically-based models to predict lap splice strength (Canbay and Frosch 2005), the results of which compare well with those of other models developed from regression analyses alone (Orangun et al. 1977; Zuo and Darwin 2000).

When subjected to cyclic loading, cracks propagate in both loading directions and may eventually join up some distance away from the rebar surface, creating regions of disintegrated concrete and hence degraded bond. The effects of reversing curvatures on large diameter bars of flexural members may also have a weakening influence on the cover (Lukose et al. 1982). However, the same authors also point out that the onset of splitting does not constitute failure and that the confinement by the stirrups allows to carry loads up to concrete spalling.

\section{Postearthquake Field Observations}

Different degrees of structural damage following past earthquakes, ranging from minor cracking to collapse, can be partly or totally attributed to the response of lap-spliced wall regions. This section presents examples of concrete structures that have undergone observable damage during recent earthquakes. Due to space limitations, column and beam damage is not included.

Damage to wall buildings associated with lap splices have been reported after some of the major earthquakes occurring during the last decade of the previous century. As examples, one can cite the damage to the Guam Hilton Hotel after the Guam 1993 earthquake (EERI 1995), or the concrete spalling that occurred in the Indian Hills Medical Center during the Northridge (California) earthquake of 1994. The RC walls in this building, which had already shown vertical splitting associated to bond-slip problems during the San Fernando earthquake of 1971, exhibited more extensive spalling over the height of the lap splice, evidencing the effects of the internal bond-slip mechanism that contributed to concrete splitting (Birely 2012).

Chimneys do not have the redundancy of wall buildings and thus a failure at a critical section will inevitably lead to its partial or total collapse. This was highlighted by the performance of two RC chimneys that failed due to poor lap splice performance. Firstly, during the Marmara 1999 earthquake in Turkey a 115-m tall RC chimney collapsed. The failure occurred at a height of 30-35 m, where an opening and lap splices were present. The structure had been designed in 1978 according to the ACI provisions in force at the time. Kilic and Sozen (2003) concluded that the most plausible cause for collapse was the association between the critical section for flexural yielding formed by the opening and the failure of lap splices at that location, which did not withstand the imposed stress reversals in the nonlinear response range. A 58-m tall chimney also failed during the Niigata-ken Chuetsu-Oki 2007 earthquake in Japan (EERIGEER 2007; Kim and Shiohara 2012). The chimney, constructed in 1994, had been designed according to the latest seismic standards, which imposed lap splice lengths of at least 40 times the diameter of the largest spliced bar. The damage concentrated at a height of approximately $17.5 \mathrm{~m}$ above the ground level where three constructional details contributed to a strength discontinuity that attracted large inelastic deformation demands: (1) splicing of the exterior layer of vertical bars, (2) cut off of the interior layer of longitudinal rebars, and (3) change from double to single transverse hoops.

More recently, damage to several of the more than 100 high-rise $\mathrm{RC}$ wall buildings that were damaged during the Chile earthquake of February 27, 2010, can be traced back to lap splice failures (Song et al. 2012). The only building with more than three stories that suffered total collapse during the earthquake was the 15-story Alto Río building, completed in 2009. Song et al. (2012) analysed possible failure sequences of the building and concluded that lap splice failure was likely to have played a role. The same authors also claim to have observed splice failures, and failures at points where bars were cut off, in at least eight other buildings in Chile. However, they do not provide further information on the lap splice configurations in these buildings.

Finally, lap splice damage in RC walls was observed after the 2010-2011 earthquakes of Canterbury in New Zealand. Sritharan et al. (2014) report the occurrence of damage about the lap splice in a 10-m long wall of a 13-story apartment building (Terrace on the Park) built in 1999. The splice had poorly detailed shear reinforcement and lack of ties between the two layers of web reinforcement. The lap splice was not located in the plastic hinge region.

\section{Past Cyclic Experimental Tests on Members with Lap Splices}

Many experimental and numerical studies have been performed on lap splice behavior to date, the majority of which focused on lap 
splice strength under monotonic loading. There is less research on lap splice strength under cyclic loads, and even more so regarding the deformation capacity of lap splices, which are two fundamental quantities that are required when modelling the seismic response of members with lap splices. The present section starts by reviewing the most relevant experimental tests carried out to date. In particular, a short summary of past cyclic tests on beams and columns is performed, followed by an extensive review of all experimental tests on walls with lap splices.

\section{Beams and Columns}

Up until the late 1970s and the extensive test programmes carried out at Cornell University on 68 beam and column specimens (Fagundo 1979; Gergely et al. 1979; Tocci et al. 1981), there was an almost complete lack of experimental data on splice performance under cyclic loading. The work performed by these researchers brought forward that the main factor that affects the rate of bond deterioration and the deterioration propagation was the amount and spacing of transverse reinforcement along the splice and just beyond the splice end (Lukose et al. 1982). Building on the observation that maintaining stirrup strains substantially below yield improves splice strength and ductility, Paulay (1982), Priestley et al. (1996), and Sivakumar et al. (1983) proposed design procedures and expressions to determine the amount of transverse confinement necessary to insure that lapped splices can sustain a large number of reversed cyclic loads just below yield level as well as some cycles into the inelastic range. Sparling and Rezansoff (1986) observed, from 12 large-scale beam tests, that such recommendations allowed the specimens to achieve appreciable displacement ductilities. Rezansoff et al. (1988), again building on the results of additional experimental tests, further underlined the need to account for the actual rebar yield strength-which can be appreciably larger than the specified yield strength-in designing the transverse reinforcement to ensure a reasonably ductile member response.

The behavior of lap splices in compression was addressed in the first half of the 1990s (Panahshahi et al. 1992) as well as the retrofit of columns with inadequate lap splices (Aboutaha et al. 1996; Chai et al. 1991; Valluvan et al. 1993). Lynn et al. (1996) and Melek and Wallace (2004) performed cyclic tests on columns with constant axial load and deficient lap splices (both in terms of splice length and confining reinforcement), typical of old building design. Lynn et al. (1996) showed that the more confined columns kept the moment capacity for larger displacement amplitude cycles, whereas the experimental program performed by Melek et al. (2003) evidenced the influence of the applied loading history on postpeak strength degradation. More recently, Pam and Ho (2010) studied the effects of the location of well-detailed lap splices on four RC columns. They concluded that the flexural strength increased slightly as the percentage of splices in the critical region also augmented, while the ductility capacity decreased due to an upward shift of the inelastic damaged region. Tests on beams with lap splices continue to date (Hardisty et al. 2015). However, as far as the authors are aware and despite the many past tests that have been performed on beams and columns, few proposals can be found regarding the ductility capacity of lap splices expressed as a function of its detailing characteristics and mechanical properties (Biskinis and Fardis 2010a; Hannewald 2013).

\section{Walls}

Tests on walls with lap splices are recent when compared with those on beams and columns described in the previous subsection. Although four wall units were tested before 2008 (Elnady 2008; Paterson and Mitchell 2003), the other 12 wall specimens with lap splices that are documented in the literature were tested over the past 6 years. The objective of the present subsection consists in carrying out a compilation of data on walls with lap splices. The following section describes also two new experimental tests (units TW2 and TW3) carried out by the authors on companion walls with and without lap splices, which complement the existing tests by considering a large lap splice length to shear span ratio, hence allowing to investigate the influence of the moment gradient on lap splice performance. In this context, Table 1 presents a complete summary of the characteristics of the walls with lap splices that were experimentally tested under cyclic loads to date along with the list of reference units with continuous reinforcement. The reinforcement layout and the main measured material properties of the specimens are depicted in Fig. 1. Observations on the behavior of each spliced test unit are provided in Table 2. As this summary can be useful to other researchers, all the information collected in Tables 1 and 2 and Fig. 1, as well as the associated experimental force-displacement data, are available through Zenodo's webpage (Tarquini et al. 2015).

\section{New Experimental Tests on Walls}

\section{Description of Experimental Tests}

Five RC walls at 2:3 scale were tested under quasi-static cyclic loading at École Polytechnique Fédérale de Lausanne within an experimental program that aimed at analyzing the effect of several parameters in the cyclic response of walls. Among them, the influence of lap splices on the in-plane structural behavior was addressed by test units TW2 and TW3. A brief description of the test setup and of the walls response follows; the data of these tests and a more detailed description of the test setup is available in Almeida et al. (2017).

Walls TW2 and TW3 were identical from the geometrical viewpoint and had a total length of $2,700 \mathrm{~mm}$, a thickness of $120 \mathrm{~mm}$, and a height of 2,000 mm. The specimens were cast with a $400 \times$ $400 \times 3,600 \mathrm{~mm}$ RC foundation, which was prestressed to the laboratory strong floor, and a $2,930 \times 420 \times 400 \mathrm{~mm}$ top RC beam to which the vertical and lateral loads were applied. Both units had a $440 \mathrm{~mm}$ flange at one extremity, which simulates the effect of a perpendicular wall on member stability. The reinforcement detailing, in which the flexural reinforcement was located on the outside of the shear reinforcement, intended to represent Central European construction practice between 1950 and 1970. The reinforcement layout of the two specimens was identical, apart from the presence of lap splices in test unit TW3, depicted in Fig. 2(a). The lap splice length was $215 \mathrm{~mm}$, corresponding roughly to 35 times the diameter of the longitudinal bars. The material properties of TW2 and TW3 are summarized in Fig. 2(b).

A sketch of the general test setup is shown in Fig. 3(a). The walls were loaded by two vertical actuators, that applied a moment and an axial load, and by one horizontal actuator. The horizontal actuator imposed cyclic in-plane displacements according to the loading protocol shown in Fig. 4. The vertical actuators were controlled such that the axial load and the shear span was constant throughout the test. The axial load was $690 \mathrm{kN}$ and the shear span $3.15 \mathrm{~m}$, which corresponds to a shear span ratio of 1.17 .

The walls were instrumented using conventional [e.g., linear variable displacement transducer (LVDTs)] and optical measurement systems, a complete description of which can be found in Almeida et al. (2017). The deformations of the wall surface were measured using a grid of 29 columns $\times 18$ rows of light-emitting diodes (LEDs) on the east face of the wall, see Fig. 3(b). On the west face of the wall the evolution of cracks was monitored with digital image correlation techniques. 


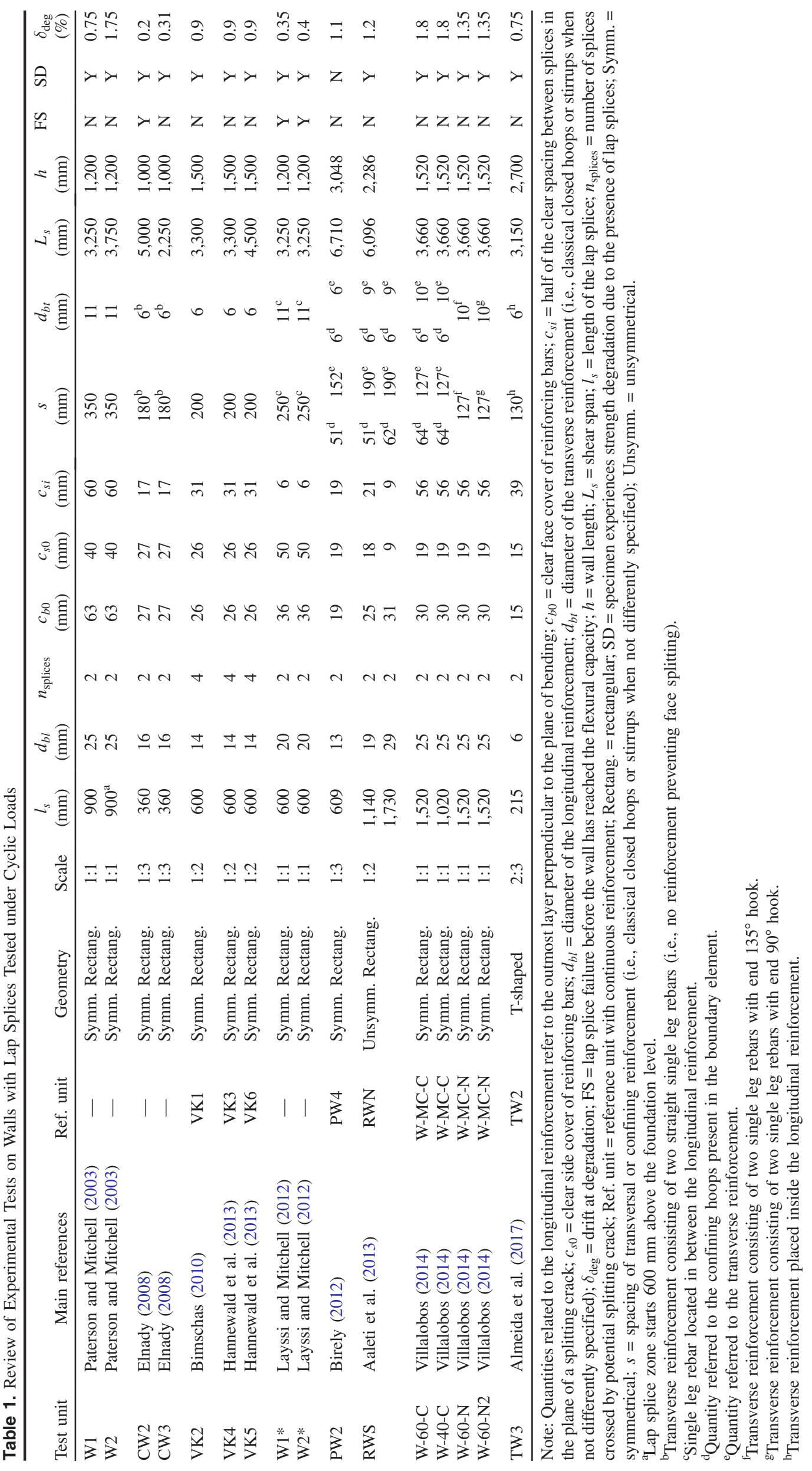




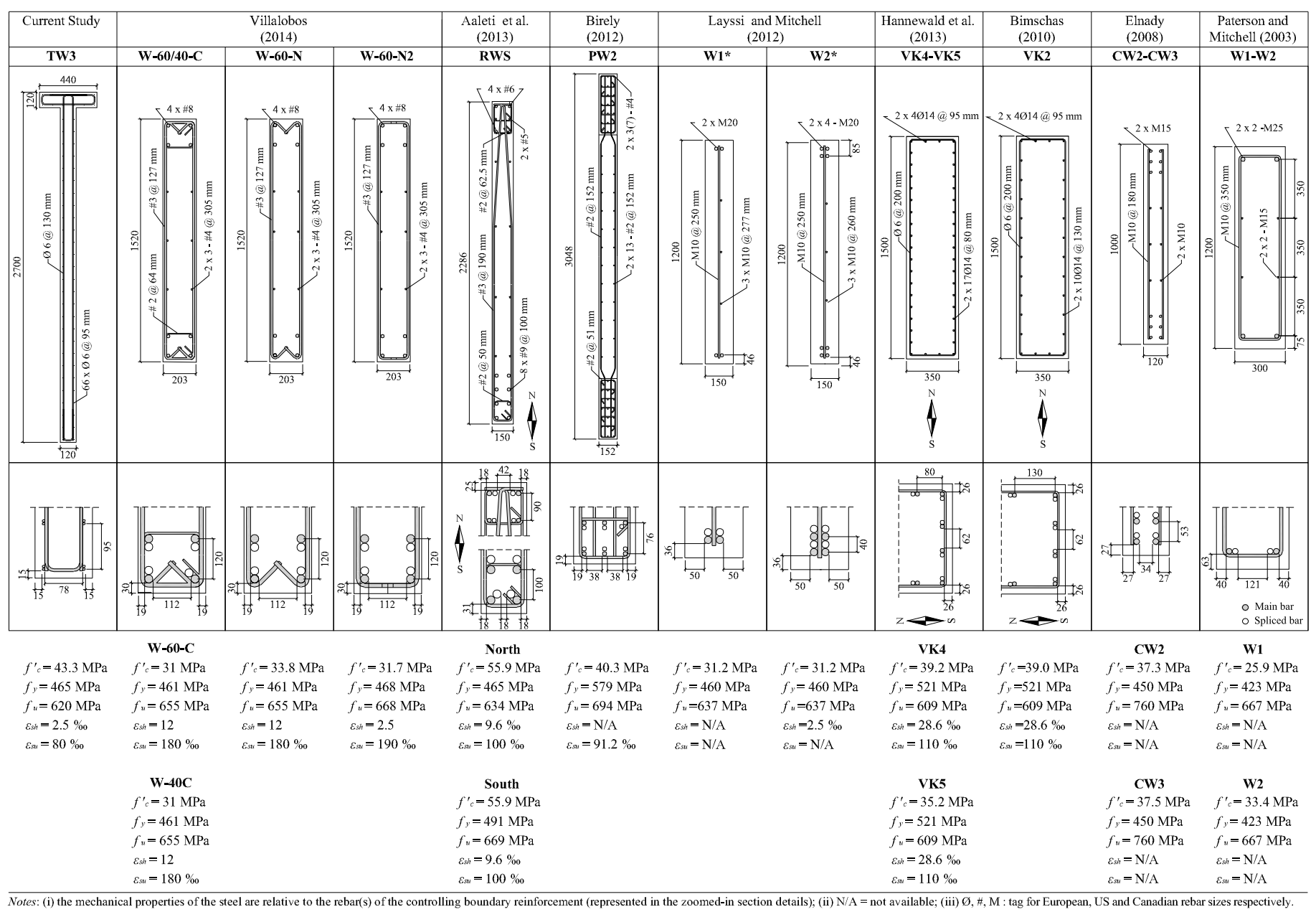

Fig. 1. Geometrical details of the wall database presented in Table 1

\section{Hysteretic Behavior and Influence of Lap Splices}

The cyclic force-displacement responses of the test units TW2 and TW3 are depicted in Fig. 5, which also includes the load stages (LS) at which different observable physical events took place. Crushing and splitting cracks were identified by the occurrence of vertical cracks, the former occurring in the compression edge of the test unit and the latter taking place in the tensile side signalling a local bond-slip failure. Table 3 summarizes the applied load and drift ratio at the occurrence of these events. Cover spalling was not clearly observed when loading toward the flanged side (i.e., flange in compression). When loaded toward the edge without the perpendicular flange (i.e., flange in tension), the test unit TW2 presented a stable hysteretic response until a lateral drift of $-0.75 \%$ (LS17). Along the same direction of loading, a loss of strength capacity of almost $50 \%$ occurred in the following cycle to $-1 \%$ (LS18 $\rightarrow$ LS19), determining the failure of the member. In this paper, failure is assumed as a $20 \%$ drop in the lateral capacity. As expected, the test unit showed a more ductile response toward the opposite direction (flange in compression) due to the presence of the flange, and only showed signs of degrading force capacity above drifts of $1.75 \%$ (LS19 $\rightarrow$ LS20).

The member response of TW3 was similar to TW2 when the flange was in tension, as shown in Fig. 5. Yet, when the flange was in compression, TW3 did not attain the same value of load capacity (7\% less, as indicated in Table 3), and the strength degradation started at a smaller drift level (after a drift of $0.75 \%$ ) resulting in a drift capacity reduction of almost $50 \%$. The reason for this reduction is the presence of lap splices in TW3, which will be discussed in the following. For the loading cycles that tensioned the flange, the well distributed crack patterns on the two walls (near the flange side) were similar. Therefore, the following paragraphs will focus mainly on the distinct local member behavior that occurred when compressing the flanged edge.

TW2 formed well-distributed shear-flexure cracks in the lower half of the wall, see Fig. 6(a). As loading progressed the width of all cracks increased approximately evenly, which is a desirable type of plastic hinge behavior. The first incipient signs of bond-slip degradation along the continuous vertical reinforcement showed up in LS18 (corresponding to a drift of 1.0\%), through minor face splitting vertical surface cracks at the edge without the flange. These cracks spread upwards and downwards (extending only for a couple of centimeters) from a few pre-existing horizontal cracks along the wall height. This is a major difference in comparison with TW3, as discussed subsequently. Fig. 7(a) shows the final condition of TW2 at the base of the nonflanged edge, which resulted from distributed concrete compression crushing above the base crack and rebar tensile fracture.

The behavior of TW3 was governed by signs that highlighted the large stress demand on the concrete in the lap splice region: Fig. 5(b) indicates that the first face splitting vertical cracks at the edge without flange appeared at the early loading stage LS08 (corresponding to a drift of $0.25 \%$ ). This should be compared with the incipient splitting cracks that appeared at $1 \%$ drift for wall TW2, see Fig. 5(a). In TW3, at LS10 (0.35\% drift), a clear 
Table 2. Main Observations on the Behavior of the Spliced Test Units Tested under Cyclic Loads

\begin{tabular}{|c|c|}
\hline Test unit & Comments \\
\hline W1 & $\begin{array}{l}\text { The specimen exhibited very poor ductility, failing soon after yielding at a lateral drift of } 0.6 \% \text {. There was a brittle failure of the lap splices at the } \\
\text { tensile end of the wall that led to a significant drop in the wall capacity. A visible vertical side splitting crack along the entire length of the lap } \\
\text { splice was visible prior to failure. }\end{array}$ \\
\hline W2 & $\begin{array}{l}\text { The wall, which had a lap splice zone located } 600 \mathrm{~mm} \text { above the foundation, showed a ductile response until almost } 2 \% \text { drift. As inelasticity (and } \\
\text { cracks) spread from the bottom and reached the height at which the splice started, a brittle tensile failure of the lap splices on one side of the } \\
\text { specimen occurred, resulting in a large drop in the capacity of the wall. }\end{array}$ \\
\hline CW2 & $\begin{array}{l}\text { At the very first loading cycle at a low drift of } 0.05 \% \text {, flexural cracks developed at the bottom of the wall and spread to near midheight. Upon } \\
\text { increasing the lateral load, the existing cracks started to open up and a new horizontal crack developed just at the top end of the lap splice zone. } \\
\text { At a drift below } 0.1 \% \text { (far below the yielding point), the wall failed prematurely due to bond slip of the lap splices. }\end{array}$ \\
\hline CW3 & $\begin{array}{l}\text { At } 0.5 \% \text { drift, two diagonal cracks were observed at inclined } \pm 45^{\circ} \text { direction. While loading, cracks opened up and extended from corner-to- } \\
\text { corner of the wall in both directions. At a horizontal drift of approximately } 1.5 \% \text {, the wall failed due to bond slip of the lap splices. }\end{array}$ \\
\hline VK2 & $\begin{array}{l}\text { The first side splitting cracks in the tensile edge of the wall appeared at } 1.5 \% \text { drift. At } 2 \% \text { drift, a large bond crack extended along the entire lap } \\
\text { splice height. By the second cycle at this drift level, the four reinforcement bars in the outmost layer of each tension zone of the cross section } \\
\text { were essentially ineffective due to bond failure of the splices. With the increase of the lateral loading, more lap splices successively failed } \\
\text { causing a subsequent progression of the cyclic strength degradation of the member. }\end{array}$ \\
\hline VK4 & $\begin{array}{l}\text { At approximately } 1 \% \text { drift, while loading in one direction, compression cracks appeared at the wall edge. At the same drift level, upon reversal, } \\
\text { splice failure occurred followed by a sensible drop of the wall strength. At the second peak at } 1 \% \text { drift, some splices at the tension side of the pier } \\
\text { also failed. At } 1.2 \% \text { drift, all cover concrete along the splices sounded hollow. The wall had reached its residual capacity (25\% of the peak force) } \\
\text { and the force-displacement relationship remained rather flat even when higher displacement levels were imposed. }\end{array}$ \\
\hline VK5 & $\begin{array}{l}\text { At } 1 \% \text { drift, vertical side splitting cracks were clearly visible along the splice length in the tension wall side. Also noticeable was a horizontal } \\
\text { crack above the splice level. During loading to } 1.5 \% \text { drift, splice failure occurred followed by a decrease of the wall lateral strength. As for VK4, } \\
\text { at this point, the specimen had reached its residual strength capacity ( } 30 \% \text { of the peak force) which remained rather constant with further } \\
\text { increase of displacement demand. }\end{array}$ \\
\hline $\mathrm{W} 1 *$ & $\begin{array}{l}\text { The wall exhibited a nonductile cyclic response due to brittle side splitting of the external lap splices prior to yielding. The specimen was able to } \\
\text { withstand only } 80 \% \text { of the predicted flexural capacity. }\end{array}$ \\
\hline $\mathrm{W} 2 *$ & Same behavior as for wall W1*. However, specimen W2* was only able to carry $68 \%$ of its predicted flexural capacity. \\
\hline PW2 & $\begin{array}{l}\text { Cover spalling initiated above the splice region at } 0.75 \% \text { drift (determined from imposed top displacements at } 3.66 \mathrm{~m} \text { ). After three cycles at the } \\
\text { same drift level, the longitudinal reinforcement was exposed and longitudinal bars buckled in the boundary element above the splice region. } \\
\text { At } 1.05 \% \text { drift, concrete crushed where buckling had occurred and the damage extended to the web of the wall, propagating down toward the top } \\
\text { of the web splices. }\end{array}$ \\
\hline RWS & $\begin{array}{l}\text { Noticeable strength degradation appeared at } 1.2 \% \text { drift with the fictitious flange in tension probably due to slipping occurring in the splice } \\
\text { region. Main cracks located approximately above the splice region and at the wall base. Bond degradation progressed increasingly with } \\
\text { displacement demand. In the end, as the crack at the wall-foundation interface became wide enough, the slip of the bars relative to one another } \\
\text { led to initial local buckling of the longitudinal reinforcement in the boundary element that contained rebars with } d_{b l}=19 \mathrm{~mm} \text {. }\end{array}$ \\
\hline W-60-C & $\begin{array}{l}\text { Splitting cracks were first observed at drift ratios ranging from } 0.25 \text { to } 0.5 \% \text {; the widest side splitting cracks occurred near the splice ends, being } \\
\text { widest near the base. At the final imposed displacement neither continuous splitting cracks along the entire splice length nor fully exposed } \\
\text { splices were present. However, the loss in strength due to bond degradation in the splice regions is easily inferable from the global } \\
\text { force-displacement response of the specimen at } 2 \% \text { drift ratio. }\end{array}$ \\
\hline W-40-C & $\begin{array}{l}\text { Similarly to the specimen W- } 60-\mathrm{C} \text {, tensile splitting cracks were observed at early stages of loading. However, before reaching the target drift } \\
\text { ratio of } 2.5 \% \text {, a crack along the entire length of the boundary splices occurred. A drop in lateral load (10 and } 4 \% \text { of the peak lateral load in each } \\
\text { direction, respectively) occurred when this crack formed. With further displacement reversals, the relative slip between splices on one face of the } \\
\text { boundary elements led to further decrease of the wall strength until the boundary elements were fully exposed. }\end{array}$ \\
\hline W-60-N & $\begin{array}{l}\text { The response of W-60-N was similar to specimen W-60-C. However, the smaller amount of confining reinforcement present in W-60-N led to an } \\
\text { anticipated onset of strength degradation occurring at a drift value of } 1.5 \%(0.5 \% \text { less than in } \mathrm{W}-60-\mathrm{N}) \text {. }\end{array}$ \\
\hline W-60-N2 & The cyclic behavior of this specimen was substantially identical to W-60-N. \\
\hline TW3 & $\begin{array}{l}\text { When loading toward the wall end without flange, the test unit failed due to crushing at the wall base. When loading toward the flange, the wall } \\
\text { exhibited a softened response due to a progressive failure of the lap splices. Most deformations concentrated in a crack above and below the lap } \\
\text { splice zone. }\end{array}$ \\
\hline
\end{tabular}
causing a subsequent progression of the cyclic strength degradation of the member.

splice failure occurred followed by a sensible drop of the wall strength. At the second peak at $1 \%$ drift, some splices at the tension side of the pier ( crack above the splice level. During loading to $1.5 \%$ drift, splice failure occurred followed by a decrease of the wall lateral strength. As for VK4, increase of displacement demand. withstand only $80 \%$ of the predicted flexural capacity.

Cover spalling initiated above the splice region at $0.75 \%$ drift (determined from imposed top displacements at $3.66 \mathrm{~m}$ ). After three cycles at the same drift level, the longitudinal reinforcement was exposed and longitudinal bars buckled in the boundary element above the splice region. of the web splices. region. Main cracks located approximately above the splice region and at the wall base. Bond degradation progressed increasingly with displacement demand. In the end, as the crack at the wall-foundation interface became wide enough, the slip of the bars relative to one another widest near the base. At the final imposed displacement neither continuous splitting cracks along the entire splice length nor fully exposed splices were present. However, the loss in strength due to bond degradation in the splice regions is easily inferable from the global ratio of 2.5\%, a crack along the entire length of the boundary splices occurred. A drop in lateral load (10 and $4 \%$ of the peak lateral load in each direction, respectively) occurred when this crack formed. With further displacement reversals, the relative slip between splices on one face of the

政 The cyclic behavior of this specimen was substantially identical to W-60-N. exhibited a softened response due to a progressive failure of the lap splices. Most deformations concentrated in a crack above and below the lap

side-splitting crack at the nonflanged edge extremity also showed up extending throughout approximately the height of the entire lap splice, see Fig. 8(a).

From cycles LS11 and LS12 onwards ( $0.5 \%$ drift), deformations of TW3 started to concentrate in the horizontal crack just above the lap splice (at around $220 \mathrm{~mm}$ above the foundation). No new cracks formed, and the pre-existing ones above the lap splices progressively reduced their width. This redistribution of stresses within the member associated to the localization of deformations is a consequence of lap splice failure. Concrete crushing localized in that same crack when loading was reversed and the wall was pushed toward the edge without flange.

At LS16 (1\% drift), following concrete cover spalling in the lap splice region, the large relative slip at the lower end of the splice could be observed visually, Fig. 7(c). Tensile failure of bars along the large crack above the lap splice involved a combination of rebar fracture and lap splice failure, Fig. 7(b). Bar rupture seems to have taken place when loading from LS17 $\rightarrow$ LS18 (1.5\% drift), when consecutive sounds of rebar rupture could be heard. At this value of lateral displacement, the wall had already lost $20 \%$ of its force capacity — see point of failure depicted in Fig. 5(b) — which further confirms that bond-slip was the triggering source of lateral load failure. Fig. 7 provides evidence on the influence of lap splices at member failure: in the wall without lap splices [Fig. 7(a), TW2], damage (concrete crushing and rebar fracture) spreads along a height of around $300 \mathrm{~mm}$, whereas in the wall with lap splices [Fig. 7(b), TW3] crushing initiates and concentrates at a single major crack above the web. Looking at the entire wall, Fig. 8(c) 


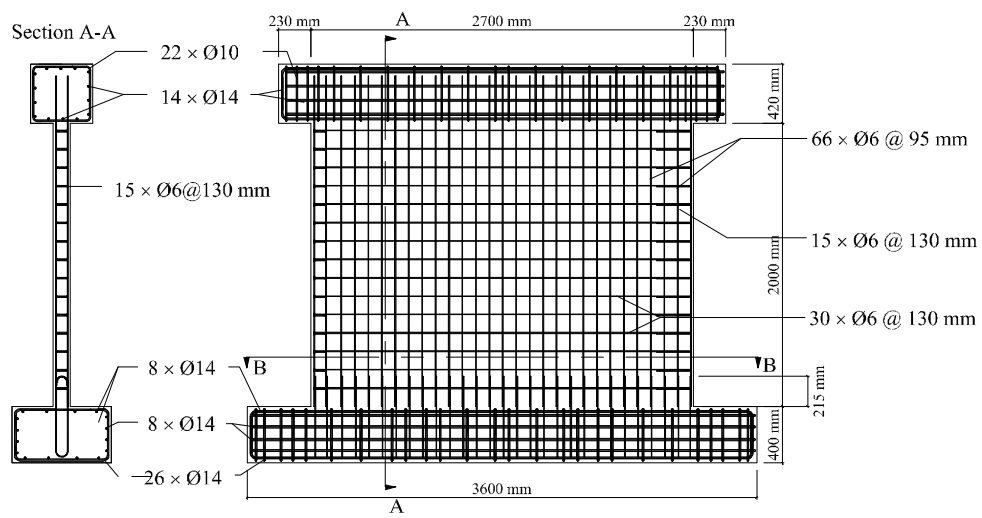

Reinforcement ratios (TW2 \& TW3)

\begin{tabular}{cccc}
\hline & $\rho_{\text {vertical }}$ & $\rho_{\text {horizontal }}$ & $\rho_{\text {orthogonal }}$ \\
Web & $0.49 \%$ & $0.35 \%$ & {$[-]$} \\
Flange & $0.64 \%$ & $0.19 \%$ & $0.35 \%$ \\
\hline
\end{tabular}

Reinforcing steel properties (TW2 \& TW3)

\begin{tabular}{|c|c|c|c|c|}
\hline$f_{y}$ & $f_{u}$ & $E_{s}$ & $\varepsilon_{s y}$ & $\varepsilon_{s u}$ \\
\hline $460 \mathrm{MP}$ & a $625 \mathrm{MPa}$ & $200 \mathrm{GPa}$ & $2.5 \%$ o $2.5 \%$ & $80 \%$ \\
\hline \multicolumn{5}{|c|}{ Concrete properties } \\
\hline & $f_{c}^{\prime}$ & $f_{t}^{\prime}$ & $E_{c}$ & $\varepsilon_{c}$ \\
\hline TW2 & $50.7 \mathrm{MPa}$ & $2 \mathrm{MPa}$ & $31.8 \mathrm{GPa}$ & $2 \%$ \\
\hline TW3 & $43.3 \mathrm{MPa}$ & $2 \mathrm{MPa}$ & $30.2 \mathrm{GPa}$ & $2 \%$ \\
\hline
\end{tabular}
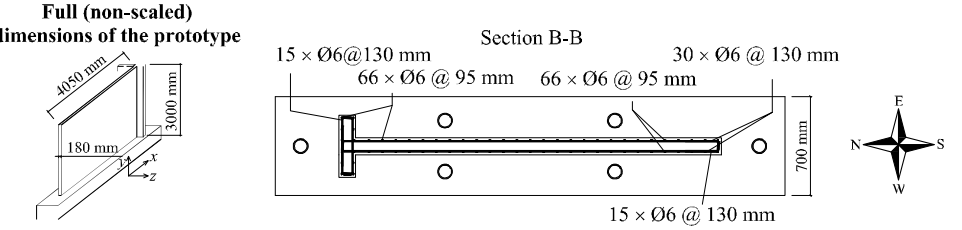

(a)

(b)

Fig. 2. (a) Geometrical and detailing characteristics of test unit TW3; (b) material properties of test units TW2 and TW3

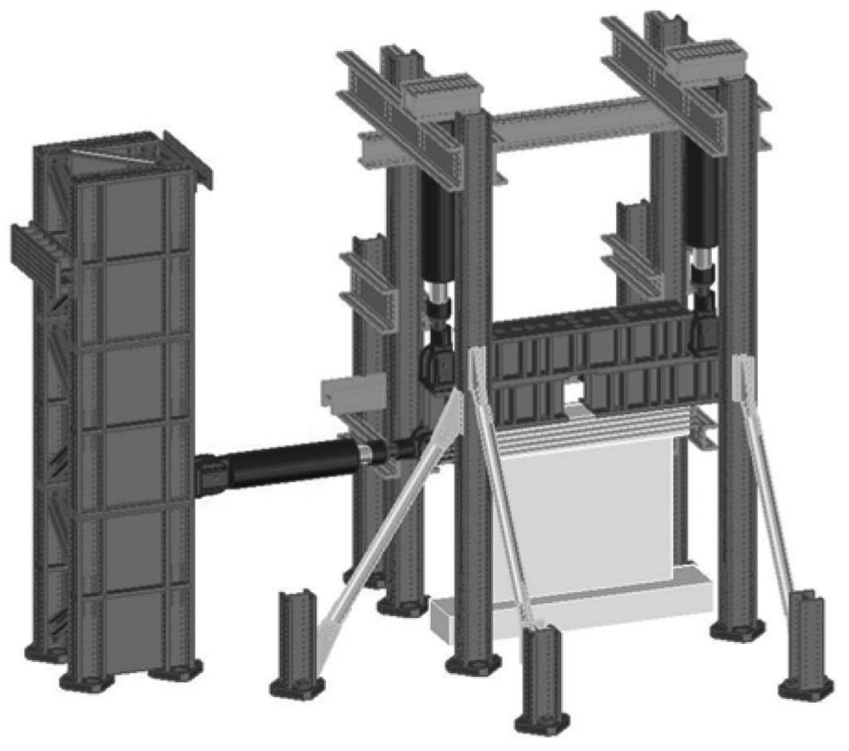

(a)

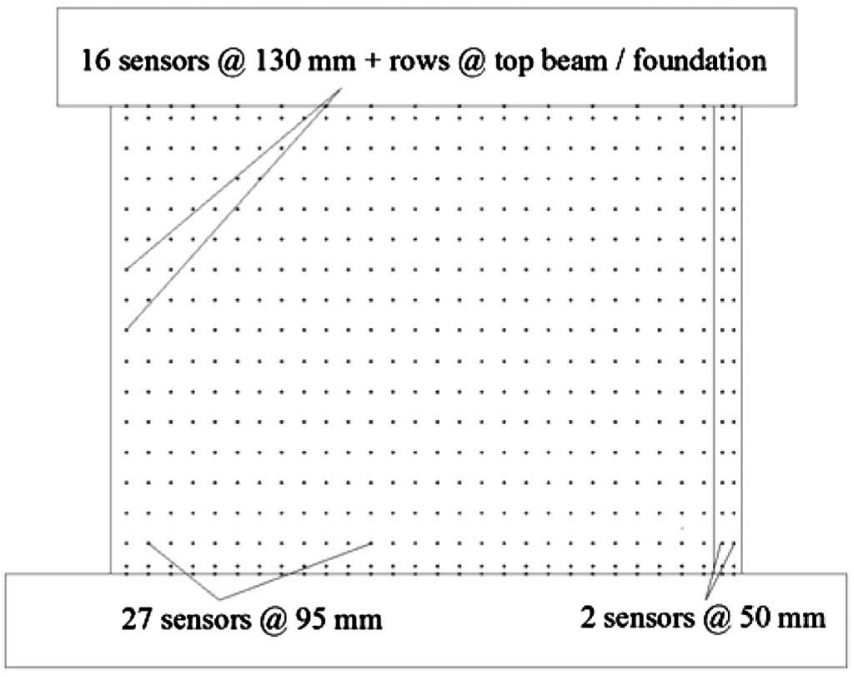

(b)

Fig. 3. (a) View of the test setup; (b) LED grid used for the optical measurement system

confirms that damage concentrated in the lap splice region, while the remaining part of the member remained largely intact, contrasting with the equivalent view of unit TW2 in Fig. 8(b).

\section{Inelastic Cyclic Response of Lap Splices in Walls Loaded in Plane}

\section{Influence of Lap Splices on Cyclic Wall Performance from Tests and Field Observations}

Based on the experimental findings in literature and the new tests, presented in the two previous sections, this section addresses the effect of wall lap splices with regard to: (1) the location of the critical section within the wall and the displacement capacity of the wall, (2) failure modes of lap splice and the influence of a moment gradient, (3) force-displacement response of walls with lap splices, and (4) the axial load bearing capacity of walls after lap splice failure.

1. Location of critical section and displacement capacity of the member: Field observations showed that lap splices often shift the critical section resisting to overturning moments and concentrate inelastic response. This was evident in the reported collapse of the chimneys during the 1999 (Turkey) and 2007 (Japan) earthquakes as well as in several buildings in Chile and New Zealand after the earthquakes of 2010 and 2011. These notes from field reports are backed up by conclusions from experimental tests (Table 2), which show that lap splices in walls reduce the displacement ductility relative to that of a wall with 


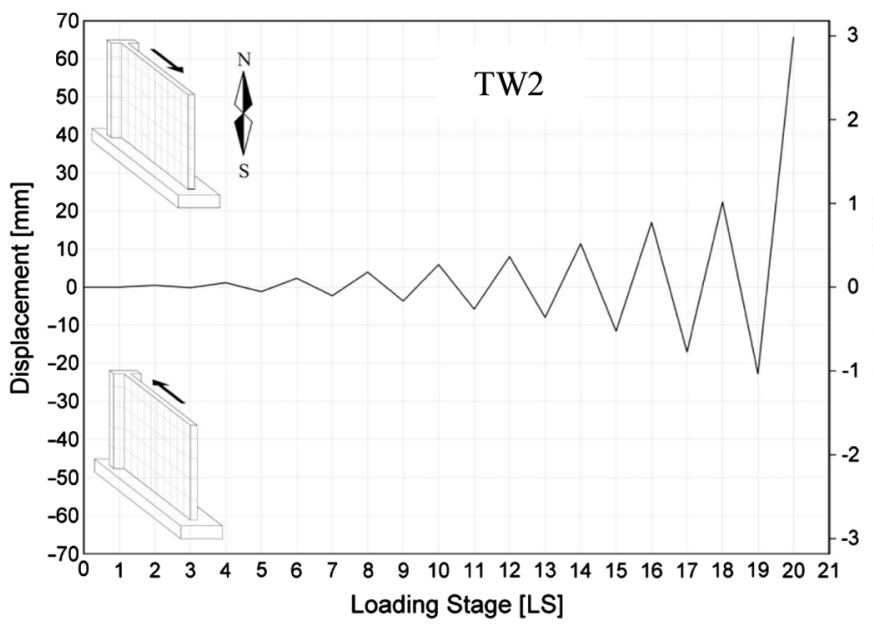

(a)

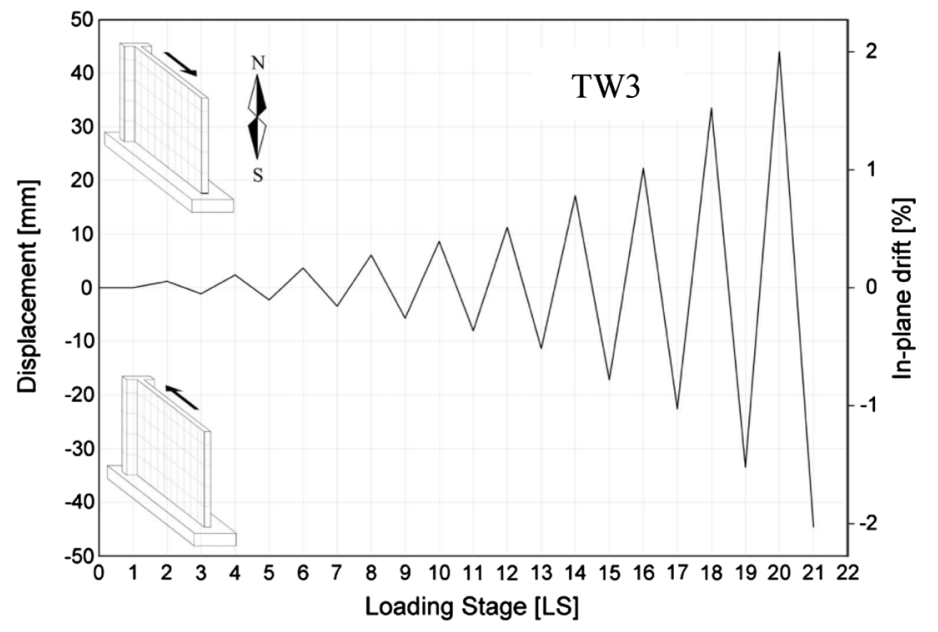

(b)

Fig. 4. Drift protocols of the two quasi-static cyclic tests: (a) TW2; (b) TW3

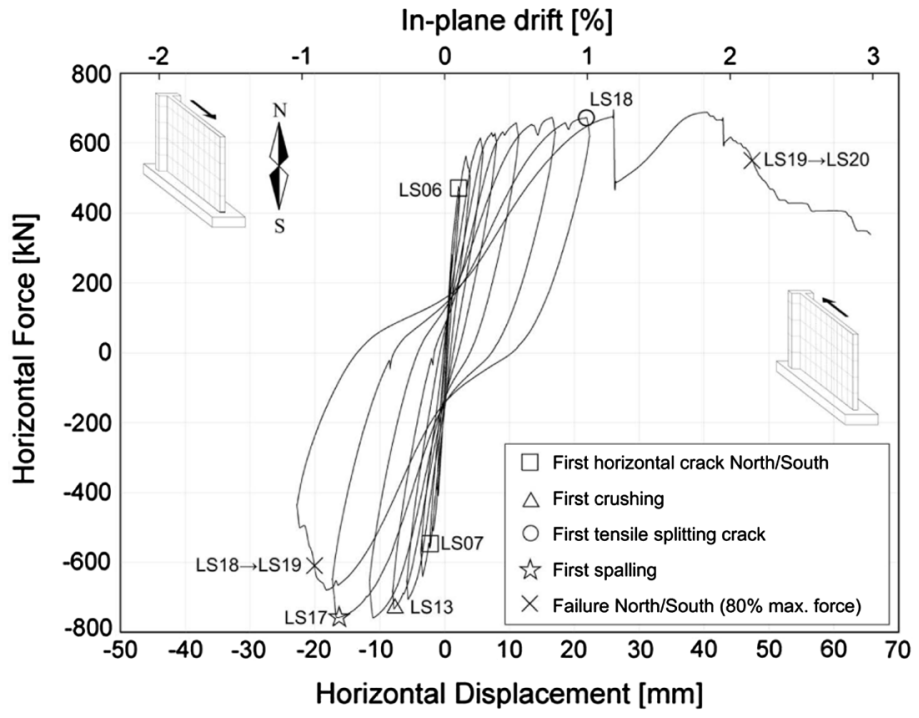

(a)

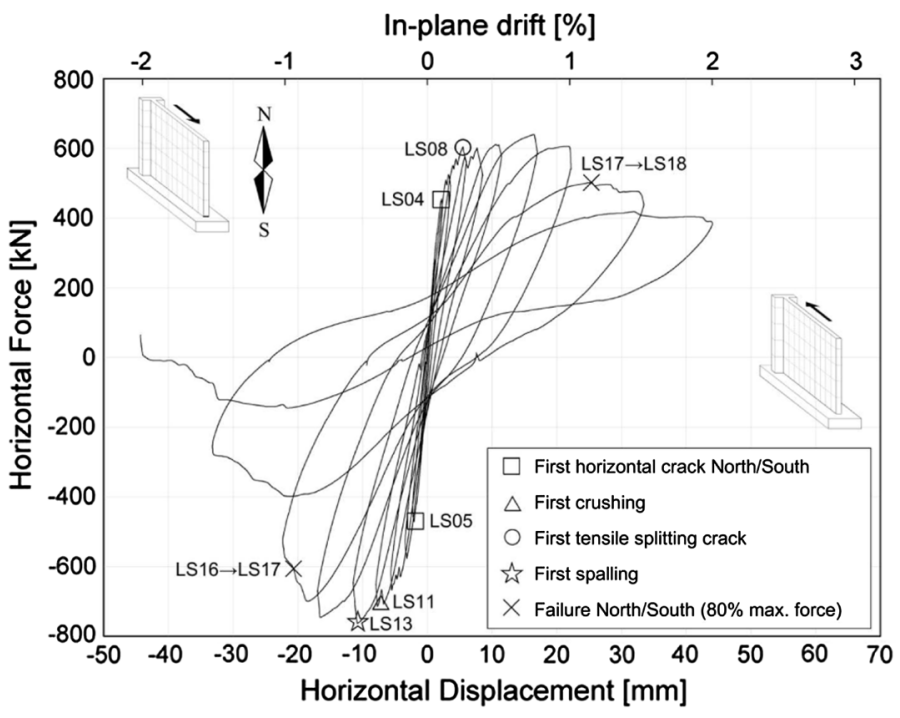

(b)

Fig. 5. Hysteretic force-displacement response of test units: (a) TW2 (note: the sudden drop occurring at a drift of approximately $1.25 \%$ was due to an emergency stop, and it should be disregarded); (b) TW3

Table 3. Summary of Applied Load and Drift Ratio at the Occurrence of Key Events

\begin{tabular}{|c|c|c|c|c|c|c|c|c|c|c|c|c|}
\hline \multirow[b]{2}{*}{ Test unit } & \multirow{2}{*}{$\begin{array}{c}\text { Load } \\
\text { direction }\end{array}$} & \multicolumn{2}{|c|}{$\begin{array}{l}\text { Horizontal } \\
\text { cracking }\end{array}$} & \multicolumn{2}{|c|}{ Spalling } & \multicolumn{2}{|c|}{ Peak load } & \multicolumn{2}{|c|}{$\begin{array}{c}\text { Drift } \\
\text { capacity }\end{array}$} & \multirow{2}{*}{$\begin{array}{l}\text { Splitting } \\
\text { crack }\end{array}$} & \multirow{2}{*}{$\frac{\begin{array}{c}\text { Bar } \\
\text { buckling }\end{array}}{\theta(\%)}$} & \multirow{2}{*}{$\frac{\begin{array}{c}\text { Bar } \\
\text { fracture }\end{array}}{\theta(\%)}$} \\
\hline & & $P(\mathrm{kN})$ & $\theta(\%)$ & $P(\mathrm{kN})$ & $\theta(\%)$ & $P(\mathrm{kN})$ & $\theta(\%)$ & $P(\mathrm{kN})$ & $\theta(\%)$ & & & \\
\hline \multirow[t]{2}{*}{ TW 2} & North & 475 & 0.10 & - & - & 688 & 1.84 & 538 & 2.16 & 1.00 & - & 1.84 \\
\hline & South & -559 & -0.11 & -759 & -0.75 & -759 & -0.75 & -607 & -0.91 & - & - & - \\
\hline \multirow[t]{2}{*}{ TW 3} & North & 455 & 0.10 & - & - & 640 & 0.75 & 501 & 1.15 & 0.25 & - & 1.00 \\
\hline & South & -471 & -0.10 & -763 & -0.49 & -763 & -0.49 & -610 & -0.93 & - & -0.49 & - \\
\hline
\end{tabular}

Note: $\theta=$ lateral drift (ratio of horizontal displacement to height of application of horizontal load).

continuous reinforcement. In walls designed according to modern detailing rules, which will require appreciable confinement of the lap splice, the plastic hinge is forced to relocate to a section above the lap splice, where damage will concentrate (e.g., in the form of concrete crushing and rebar buckling/fracture), leaving the lap splice region largely undamaged (Lowes et al. 2012). Shifting the plastic hinge to a section above the lap splice reduces the member ductility, as previously observed for columns (Pam and Ho 2010), and also increases the shear demand on the wall. 


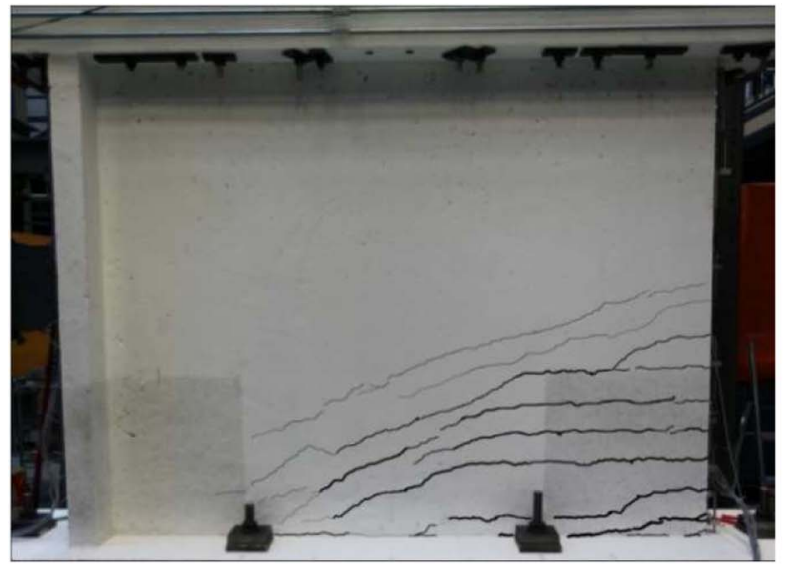

(a)

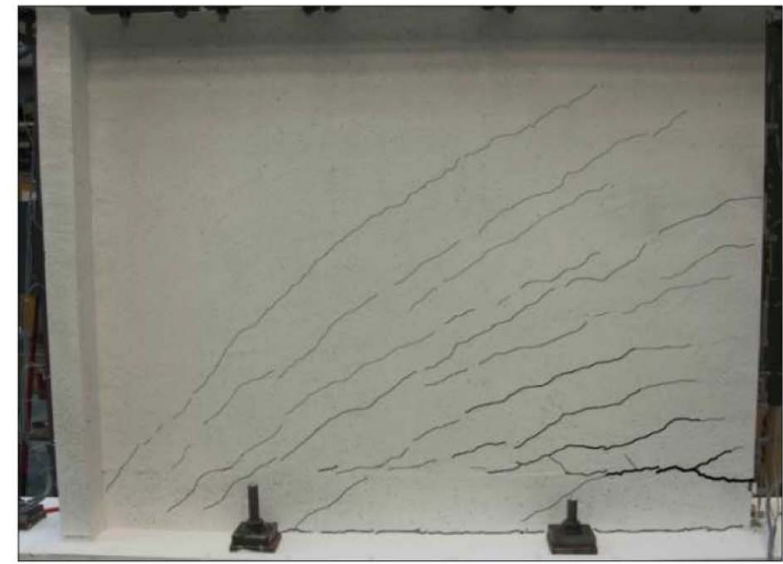

(b)

Fig. 6. Crack pattern at $0.75 \%$ drift: (a) TW2; (b) TW3

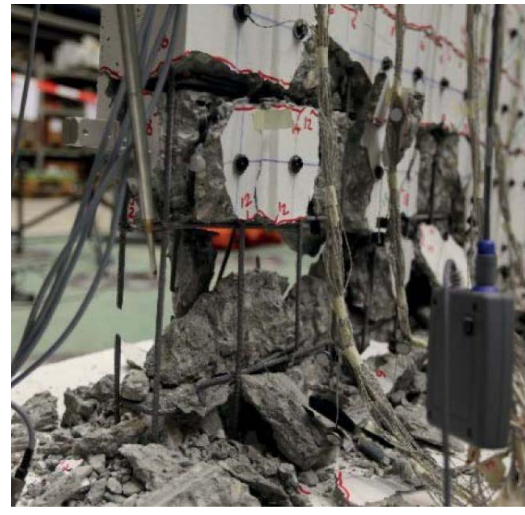

(a)

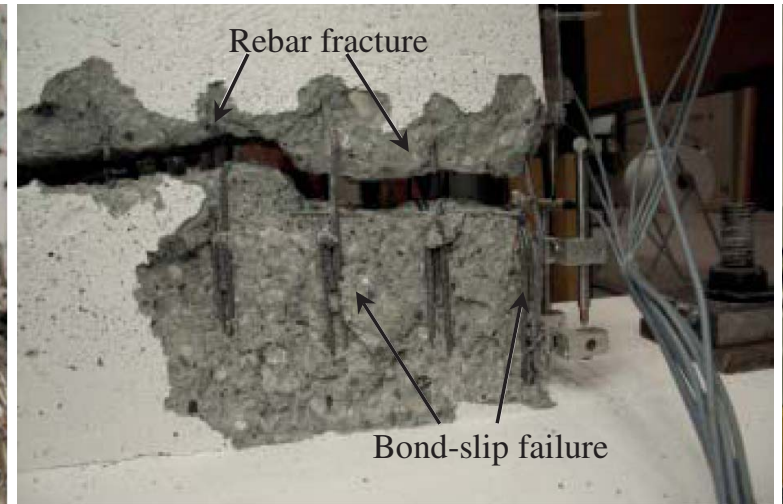

(b)

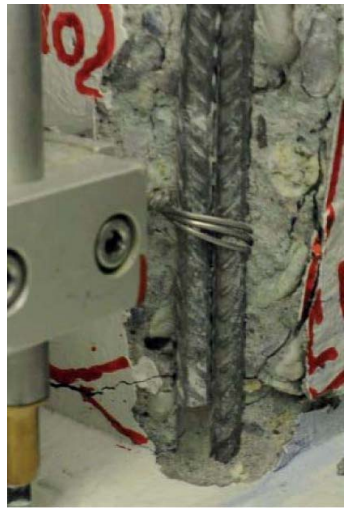

(c)

Fig. 7. Base of the wall edge without flange in the last load stage: (a) TW2; (b) TW3; (c) photographic evidence of bond-slip failure in TW3 at LS16 (1\% drift), after spalling at the corners

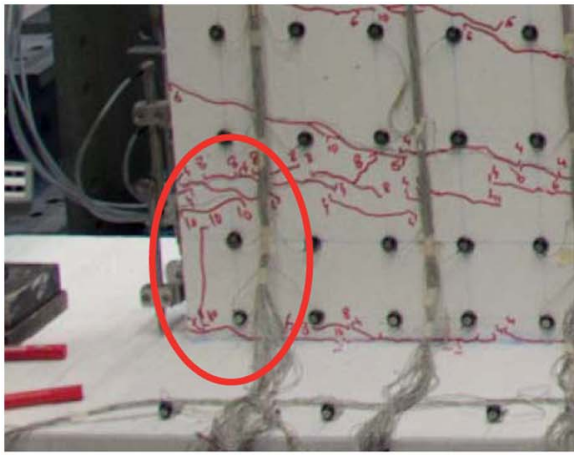

(a)

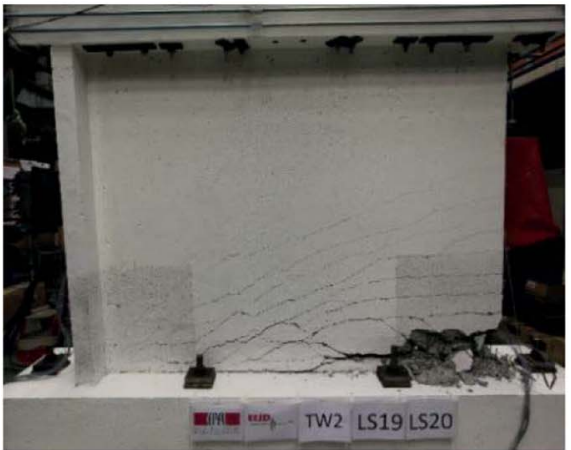

(b)

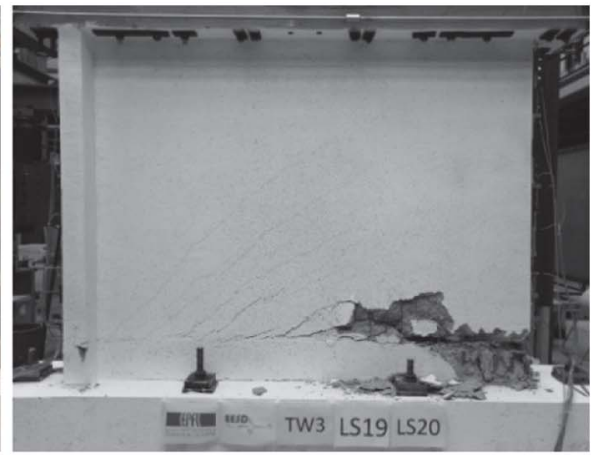

(c)

Fig. 8. (a) Occurrence of side-splitting crack along the lap splice height for TW3, at LS10 (0.35\% drift); visual condition of the walls at last load stage before the end of the test, wherein both specimens were resisting approximately to $60 \%$ of the peak force; (b) TW2; (c) TW3

For walls with lower horizontal reinforcement ratios $\left(\rho_{h}<\right.$ $0.25 \%)$ or shorter lap splices $\left(l_{s}<40-45 d_{b l}\right)$, damage generally first manifests in the form of splitting cracks along the lap splice length. As the imposed member displacement demand further increases, bar slippage shows up in the formation of horizontal cracks at the top and bottom of the lap splices.
Finally, if the wall lap splice region is not adequately confined, a corresponding reduction of the splice deformation capacity is inevitable, and consequently the member flexural ductility capacity also diminishes. For cases of poor transverse reinforcement or short lap splices, the flexural yield member strength may not even be attained and a sudden brittle failure will occur. 
2. Failure modes of lap splices and influence of a moment gradient: Lap splices can fail in three modes, i.e., (1) tension failure, (2) tension failure upon load reversal after concrete crushing in compression took place, and (3) compression failure of the lap splice in conjunction with crushing of the concrete. The latter is uncommon in walls (compression failure tends to initiate in the crack above the lap splice) but the two first modes have both been observed. When walls are tested under cyclic loads, it is often difficult to distinguish between these two modes. During quasi-static cyclic tests, the onset of formation of splitting or crushing cracks indicates whether failure of the splice initiated when it was in tension or in compression, respectively.

Member failure due to lap splices does not imply that all rebars must fail through a bond-slip mechanism. In fact, mix of bar fractures and splice failures were observed both in postearthquake scenarios, such as in the Alto Río building in Chile (Song et al. 2012), and in experimental tests, such as wall TW3 as depicted in Fig. 7(b).

The existence of a moment gradient (shear) over the lap splice length appears to be another fundamental aspect in the behavior of walls. Although the presence of shear and therefore a gradient in tension force over the length of the lap splice is in principle beneficial to its performance (see discussion on factors affecting lap splice response in the next section), it can lead to degradation of the lateral load capacity due to the occurrence of a single widening flexural crack just outside the high moment end; hence, closely spaced confinement should be extended to the neighbouring region whenever possible in design.

3. Force-displacement response of walls with lap splices: The analysis of the cyclic force-displacement responses of the wall specimens collected in the database, depicted in Fig. 14 of Tarquini et al. (2017), indicate that the failure of the outermost layer of lap splices typically signals a marked specimen strength degradation and can be hence assumed as member failure. The displacement corresponding to this onset of degradation, as observed from the experimental tests $\left(\Delta_{\text {deg }}\right)$, is also indicated in the previously mentioned figures. In Table 1 the corresponding drift $\left(\delta_{\text {deg }}\right)$, defined as the ratio between $\Delta_{\text {deg }}$ and the specimen height, is reported. Pinching of the hysteresis curves after such onset of lap splice strength degradation are also evident in many tests, indicating bond deterioration and slip along the lap length, which is a type of behavior that had been also observed in beam tests (Sparling and Rezansoff 1986). Additionally, past experimental programs on columns showed the large sensitivity of the postpeak branch to variations of the loading history (Melek et al. 2003).

4. Axial load bearing capacity of walls after lap splice failure: Lap splice failure originates a rocking type of response that does not necessarily result in overturning (Hannewald 2013; Song et al. 2012). However, it is believed that such type of lap splice response in relatively thin $\mathrm{RC}$ walls is not reliable because it is uncertain whether the wall base can endure the impacts associated with rocking (which can cause concrete crushing) and because a lateral out-of-plane shift of the wall can occur due to ground motion components in the perpendicular direction or torsional effects. Song et al. (2012) name the same causes for the collapse of the Alto Río building in Chile. Conversely, in bridge piers that are typically wider than walls, the rocking response after lap splice failure might be rather stable (Hannewald et al. 2013). Finally, in walls with insufficient shear reinforcement, a premature lap splice failure might precede a shear failure (Hannewald et al. 2013). Lap splices might therefore act as a fuse, which prevents the loss of the axial load bearing capacity entailing from shear failure.

\section{Factors Affecting Lap Splice Strength and Strain at Degradation Onset}

With a view to contribute to seismic modelling tools, the three following quantities define the basic corner points of an equivalent uniaxial stress-strain curve for lap splices of longitudinal reinforcement in cyclically loaded walls:

1. Strength: Lap splice strength has been thoroughly addressed over the last decades and therefore its influencing factors are well known, particularly in the context of monotonic loading. Discussions and computation of lap splice strength are inseparable from the concept of bond stress, which plays a central role in most strength prediction models and code prescriptions. They are typically based on estimations of an average bond stress (averaged over bar lengths of at least 18 bar diameters). It is noted that local bond stresses, derived from measurements along shorter distances of one to three bar diameters (Eligehausen et al. 1983) can be four to five times larger (ACI 2012).

2. Strain at degradation onset: Average strains within the splice length at the onset of degradation were seldom measured in past experimental tests. However, this is a fundamental quantity for the development of an equivalent constitutive model for lap splices. From analysis of experimental and numerical results (Tarquini et al. 2017), it appears too conservative to assume that the strain at the onset of cyclic strength degradation corresponds to the lap splice strength divided by the steel Young's modulus. Despite its relevance for simulation purposes, the authors could only find few proposals in the literature regarding the strain capacity of lap splices (Biskinis and Fardis 2010b; Hannewald 2013; Priestley et al. 1996), of which only one expression for the maximum tensile strain that the lap splice can sustain (Biskinis and Fardis 2010b).

3. Residual strength and strain: Upon the onset of lap splice degradation, the strength of most test units with lap splices dropped sharply whereas for two test units the loss of strength was more gradual (TW3 and VK2). Postpeak response modelling is a delicate task as it requires challenging procedures to match numerical and physical localization issues (Almeida et al. 2012, 2016; Calabrese et al. 2010). This applies in particular to brittle deformation mechanisms such as lap splices, which are often characterized by steep softening slopes. Both under monotonic and cyclic loads, some resistance is maintained even at large values of bar slip due to friction and interface shear (ACI 2012), which is however difficult to quantify. The derivation of expressions to estimate both lap splice strength and the strain at the onset of cyclic degradation relies on a correct identification of the corresponding governing factors. Many expressions are available in the literature to estimate the monotonic strength of lap splices because the corresponding influencing factors are well identified and there is sufficient experimental test data for calibration and statistical validation. It can be expected that most factors governing the monotonic strength also significantly influence the response under repeated or reversed cyclic loads. For what concerns the strain at the onset of degradation, scarcer experimental results are available. The governing parameters are therefore retrieved from regression analysis of the simulated wall database, which is detailed in the companion paper (Tarquini et al. 2017). A summary of the determined key factors influencing both lap splice strength and strain at the onset of degradation is given in the following.

\section{Splice Length}

Design and assessment codes assume an average (constant) bond strength for concrete that is estimated based on a number of parameters (ACI 2012). The lap splice length is not among them, which is 
at odds with the established decades-long observation that there is a nonlinear relation between splice length and splice strength (Chinn et al. 1955; Ferguson and Krishnaswamy 1971). In fact, under monotonic loading the effectiveness of a splice reduces with the increase in length as the bond stress throughout the length progressively changes from an approximately constant distribution to one wherein stress concentrates at the splice extremities (Canbay and Frosch 2005). Further, it is also known that this bond stress concentration is more pronounced for smaller diameters, and hence the ratio between the lap splice length and the bar diameter should be the controlling parameter. As stated in Song et al. (2012), who used data reported by the ACI (2001) and Seliem et al. (2009), the monotonic unit bond strength of unconfined deformed bars with relatively small cover shows a clear inverse proportionality with the previously noted ratio. Canbay and Frosch (2005) analyzed a database of 203 beam tests containing lap splices in constant moment regions with splitting failure and estimated that splice strength is proportional to the square root of the ratio lap splice length-bar diameter.

The extent to which the previous observations apply to cyclic response is still not clear. However, as discussed subsequently, it is known that transverse confining reinforcement plays a fundamental role to ensure that longer lap splices perform well under cyclic loading. If an adequate confinement is not provided to prevent bond strength degradation, additional lap length is of little added value as yielding will quickly penetrate from one or both ends accompanied by progressive longitudinal splitting. Paulay (1982) named this succession of events as an unzipping phenomenon.

Lap splice length is also strongly correlated to the average lap splice strain capacity. This effect can be also observed at the member level regarding the drift $\delta_{\text {deg }}$ at the onset of strength degradation, see Fig. 9(a). As discussed in the next subsection, the abscissa coordinate depicts the ratio between the lap splice length and the shear span, but it is the former variable that relevantly affects this trend. In contrast, the statistical correlation for the lap splice strain capacity does not improve when the ratio between the splice length and the rebar diameter is considered.

\section{Moment Gradient}

Most experimental tests to date were carried out on lap splices in beam and column regions subjected to constant moment (Chinn et al. 1955). When the effect of moment gradient was first studied under monotonic loading, some researchers proposed simple modifications for the splice strength to account for the ratio between the smaller and the larger stress at the two splice ends (Ferguson and Briceno 1969; Ferguson and Krishnaswamy 1971), although others observed that, for tests below yield and from a statistical analysis of the collected database, the effect of moment gradient did not seem relevant enough to justify an inclusion in the developed expression for the bond strength (Orangun et al. 1977).

As further experimental evidence accumulated, it became clear that a moment gradient along the lap splice was always unquestionably beneficial for splice performance. In fact, without shear (uniform moment), damage progresses from both ends of the splice potentiating its detrimental interaction. With increasing shear (and thus larger moment gradients) the failure initiates from the extremity with higher moment and the interaction between the two ends is reduced. The specimens with shear tested at Cornell University sustained unequivocally a larger number of cycles above $95 \%$ of yielding than the specimens under constant moment (Lukose et al. 1982).

Because lap splice tests with varying moment are difficult to interpret and provide larger estimates of bond strength (Canbay and Frosch 2005), most available expressions for the prediction of lap splice strength do not account explicitly for the effect of the moment gradient.

For RC walls with continuous longitudinal reinforcement, plasticity spreads along the member as the moment gradient decreases, enabling the member to achieve a larger ductility capacity. For many decades, most expressions for the plastic hinge length have thus reflected this effect, wherein the moment gradient is represented by the shear span (Priestley et al. 2007). As mentioned in the beginning of this subsection, the moment gradient along the lap splice is also expected to influence its ductility. However, unlike for continuous longitudinal reinforcement, a larger moment gradient is now expected to increase the ductility capacity. This effect has been mentioned in recent wall tests with lap splices (Hardisty et al. 2015; Villalobos et al. 2017). Because the member shear span only insufficiently reflects the effect of the moment gradient along the lap splice, the ratio between the lap splice length and the shear span should be considered instead, see Fig. 12(b) of Tarquini et al. (2017). At the member level, the influence of this ratio on the drift at degradation onset $\delta_{\text {deg }}$ is also apparent, see Fig. 9(a).

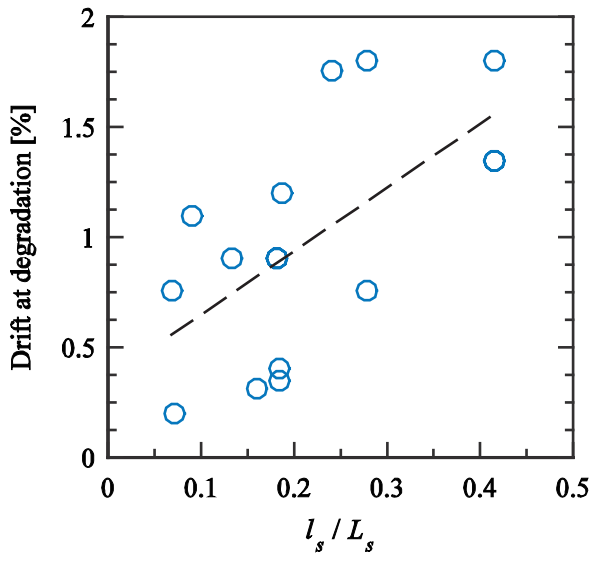

(a)

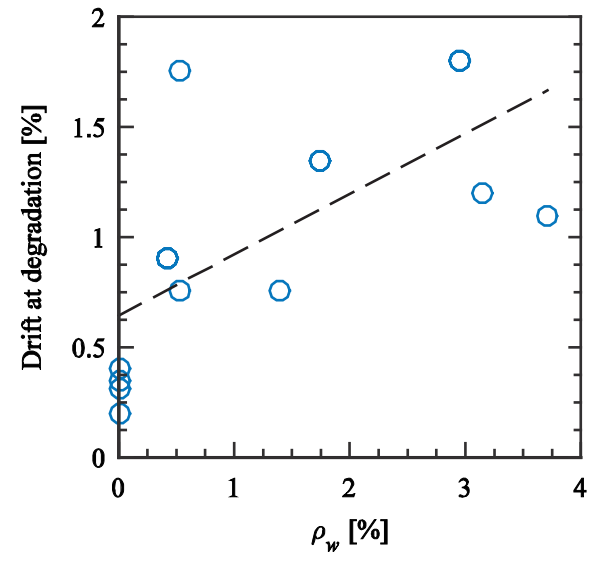

(b)

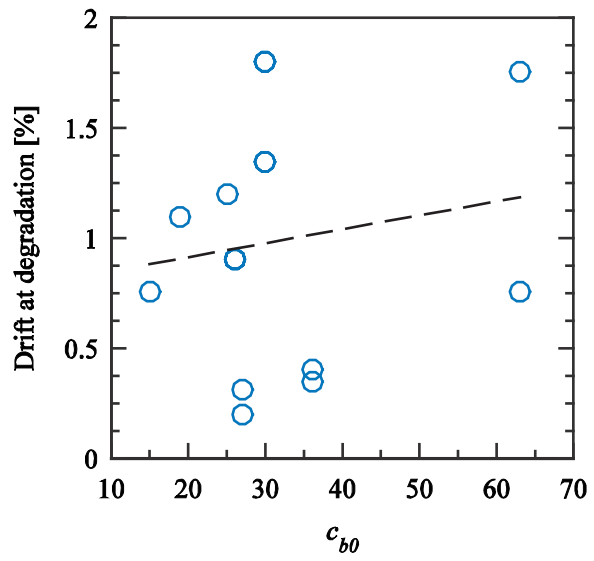

(c)

Fig. 9. Experimental data and linear regression (dashed line) relating drift at onset of strength degradation with: (a) ratio between lap splice length and shear span; (b) confining reinforcement ratio; (c) clear face cover of reinforcing bars 
Finally, it is observed that this effect on lap splices in walls is expected to be possibly more detrimental than along column lap splices in ductile frames. In fact, whereas for the latter the shear span varies typically between half and the total story height, the shear span at the wall base in a building with more than 4-5 stories can be a multiple of the story height, therefore inducing a close to uniform moment profile along the lap splice length.

\section{Transverse Reinforcement}

Transverse (confining) reinforcement is the most critical factor in the response of lap splices, both regarding strength and strain at degradation onset. The effect of transverse reinforcement is particularly important after tensile splitting has taken place, because splitting planes inevitably cross layers of transverse reinforcement (Priestley et al. 1996). The tension stress in the hoops allows to transfer bond stresses between bars and concrete via a shear friction mechanism (Priestley et al. 1996). Transverse reinforcement delays yield penetration rate into the splice (Lukose et al. 1982). It has been shown experimentally that specimens with well-confined lap splices can sustain many cycles of repeated load up to a displacement ductility of at least two, before failure (Lukose et al. 1982; Sparling and Rezansoff 1986).

However, a large amount of transverse reinforcement can bring undesired consequences. By limiting yield penetration into the splice region, the plastic hinge length may reduce significantly. The curvature ductility required to attain the imposed lateral displacement will therefore increase, resulting potentially in large steel strains, excessive strain hardening, and possible fracture of longitudinal reinforcement (Paulay 1982). Conversely, and alternatively, splices detailed according to modern codes can force wall damage to occur at the top of the splice, thus relocating the critical section and reducing the member drift capacity (Lowes et al. 2012; Pam and Ho 2010).

Based on tests of four columns subjected to monotonic tensile loading and four columns under severe load reversals, AristizabalOchoa et al. (1980) concluded from strain measurements in transverse reinforcement that hoops at the ends of the splice are more effective than interior hoops in confining the lap splice and that an insufficient amount can lead to a reduction in deformation capacity and strength. This observation is coherent with the previous comments regarding the concentration of bond stress at the extremities of long lap splices under monotonic behavior. However, as discussed in ACI (2012), the comprehensive research carried out at Cornell University (Fagundo 1979; Gergely et al. 1979) observed that the bursting forces tended to distribute uniformly along the lap splice as yield penetration progressed, concluding that uniform stirrup spacing provides the most effective confinement for cyclic loading, which confirmed the early studies by Muhlenbruch (1948). These observations seem to indicate that cyclic loading contributes to smooth the rebar strain and stress demands along confined lap splices, hence supporting the use of an equivalent steel constitutive model for the entire region.

Fig. 12(a) of Tarquini et al. (2017) shows that the average lap splice strain capacity correlates strongly with the confinement reinforcement. At the member level, the displacement at the onset of lap splice degradation also correlates with the confinement reinforcement ratio, as shown in Fig. 9(b). A possible justification is the increased significance of the shear friction component after splitting cracks have formed, enabling the transfer of forces between two spliced bars and a more efficient yield penetration along the lap splice without sudden strength degradation (Priestley et al. 1996). This comes in line with the consideration that the frictional mechanism in the postyield range represents an important contribution. In particular, low levels of strains at degradation onset were observed for those specimens that presented no stirrup branches between the lap splices and the side or face surfaces (or both), i.e., when at least one splitting crack could freely develop from the rebars to the surface.

\section{Concrete Cover, Longitudinal Bar Spacing, and Diameter}

All the specimens summarized in Table 1 with lap splice degradation developed splitting cracks. The occurrence of this failure mode (instead of pull-out) can be mainly ascribed to the fact that all specimens had a concrete cover less than 2.5 bar diameters. In the presence of closely spaced stirrups, splitting brings about an increase in ductility and energy absorption, facilitating a redistribution of forces and a nearly constant bond stress along the splice (Lukose et al. 1982; Priestley et al. 1996).

Concrete cover, bar spacing, and diameter are directly taken into account for the computation of the lap splice strength. However, they do not seem to have a clear influence on the strain capacity at degradation onset, possibly because they vary within a narrow range for most of the walls in the database. Fig. 9(c) shows that, at the member level, the drift at degradation onset $\delta_{\text {deg }}$ is also not sensitive to the clear face cover of reinforcing bars.

\section{Cyclic Loading}

The tests at Cornell University (Lukose et al. 1982) showed that repeated loading and the number of load cycles have little effect on lap splice behavior if the load level is below approximately $75 \%$ of the monotonic capacity. However, when not appropriately confined, the rate of bond deterioration in lap splices increases rapidly even for a few cycles close to yield, also because excessive compressive strains will cause microcracks that will in turn reduce the tensile concrete strength (Priestley et al. 1996). To overcome this problem, Paulay (1982) and Sivakumar et al. (1983) proposed rules for adequate design of confining reinforcement, and demonstrated experimentally that they allow lap splices to safely sustain cycling up to $95 \%$ of its ideal flexural strength, and even to perform satisfactorily in the inelastic range for many cycles of low ductility demands.

It is also well known that fully reversed cyclic loads are significantly more unfavourable to lap splice performance than repeated unidirectional loads, which can be readily explained by the progression of physical damage induced by cyclic loads. The beam tests carried out by Sparling and Rezansoff (1986) are exemplary illustrations of this effect: although a well-confined reference unit tested under monotonic loading reached $123 \%$ of the yield load at a displacement ductility of 4.37 and an identical beam loaded under repeated unidirectional loads sustained 579 cycles between 109 and $130 \%$ of the yield load up to a ductility of 3.91 , the specimens that were subjected to reversed cycling at $109 \%$ of the yield load resisted only to $56-175$ cycles, failing at considerably smaller ductilities of 2.04-2.87.

The previous observations suggest that the error associated with using existing expressions for monotonic splice strength to estimate the capacity of specimens under seismic loading is acceptable. The comparison of the experimental data and the results of the numerical simulations in the companion paper (Tarquini et al. 2017) confirms that, for the loading protocols imposed in the wall tests performed by the authors, such hypothesis is valid and will thus be adopted.

\section{Other Factors}

Bond strength before the development of splitting cracks is directly related to the tensile strength of concrete, which in turn is often expressed as a function of the compressive strength. The relatively small size of the wall database combined with the narrow range of concrete compressive strengths of the test units, depicted in Fig. 1, did not allow to draw any conclusions with regard to the possible influence of this variable on the strain at degradation onset. 
Other factors influencing lap splice behavior (ACI 2012) are not addressed in this paper, owing to space limitations and also because they fall outside the scope of the present study. Among them, the wall length appears to be of possible relevance because the regression analysis of computed strains at degradation onset showed that these values tend to be larger for longer walls. This dependency can perhaps be explained by an increasing relevance of the shear deformation mechanism for longer walls after flexural stiffness drop due to rebar yielding and progression of splitting cracks, which would thus delay the occurrence of strain degradation at lap splices. Nevertheless, as most of the members in the database have lengths in the reduced band of 1-1.5 m, the authors preferred to neglect such parameter and to not extrapolate the relation for larger (more realistic) values of wall lengths. Other influencing factors on the lap splice strength, and possibly on the strain at degradation onset, include the relative rib area (namely smooth versus ribbed bar), casting position, concrete vibration, reduction of bond strength due to epoxy coating (Hester et al. 1993), type of concrete [ACI 318M11 (ACI 2011)], corrosion level, presence of alkali-silica reactions, temperature, and the effect of steel or polymer fibres in concrete.

\section{Conclusions}

Field evidence collected after recent earthquakes has shown that the cyclic inelastic response of many RC wall structures was adversely affected by the presence of lap splices, including cases in which such structures were designed according to modern codes. A number of experimental campaigns were launched during the last years to better understand the full extent to which such constructional detail impacts the inelastic cyclic performance of walls. The present paper collected and systematized the results of all such tests, which are constituted by 16 walls with lap splices and eight reference units with continuous reinforcement. They include a recent test campaign performed by the authors involving two large-scale walls (one with and one without lap splices). The latter complement the existing tests by investigating a member with a large lap splice length to shear span ratio, which allowed to investigate the influence of the moment gradient on the lap splice performance.

The assembled database allowed for identification of the factors that most crucially influence the displacement ductility of walls with lap splices. This aspect, of fundamental relevance in seismic engineering applications, has not been the object of extensive studies in the past, which focused mainly on the determination of the strength of lap splices. The displacement ductility of members with la splices was shown to be mainly affected by the confining reinforcement, moment gradient, lap splice length, and loading history. They are used in the companion paper to derive an expression to estimate the strain at the onset of splice degradation.

\section{Acknowledgments}

The financial support by the Stiftung zur Förderung der Denkmalpflege to the project "Erbebenverhalten von bestehenden Stahlbetongebäuden mit dünnen Wänden" and by the Swiss Federal Roads Office (FEDRO) to the project number AGB 2015/002, under which the present study was partly carried out, is acknowledged.

\section{References}

Aaleti, S., Brueggen, B. L., Johnson, B., French, C. E., and Sritharan, S. (2013). "Cyclic response of reinforced concrete walls with different anchorage details: Experimental investigation.” J. Struct. Eng., 10.1061 /(ASCE)ST.1943-541X.0000732, 1181-1191.
Aboutaha, R. S., Engelhardt, M. U., Jirsa, J. O., and Kreger, M. F. (1996). "Retrofit of concrete columns with inadequate lap splices by the use of rectangular steel jackets." Earthquake Spectra, 12(4), 693-714.

ACI (American Concrete Institute). (2001). "Development and splice lengths of uncoated bars." ACI 408, Farmington Hills, MI.

ACI (American Concrete Institute). (2011). "Building code requirements for structural concrete." ACI 318M-11, Farmington Hills, MI.

ACI (American Concrete Institute). (2012). "Report on bond of steel reinforcing bars under cyclic loads." Joint ACI-ASCE Committee 408, Farmington Hills, MI.

Almeida, J. P., Das, S., and Pinho, R. (2012). "Adaptive force-based frame element for regularized softening response." Comput. Struct., 102, $1-13$.

Almeida, J. P., Prodan, O., Rosso, A., and Beyer, K. (2017). "Tests on thin reinforced concrete walls subjected to in-plane and out-of-plane cyclic loading." Earthquake Spectra, 33(1), 323-345.

Almeida, J. P., Tarquini, D., and Beyer, K. (2016). "Modelling approaches for inelastic behaviour of RC walls: Multi-level assessment and dependability of results." Arch. Comput. Methods Eng., 23(1), 69-100.

Aristizabal-Ochoa, J. D., Fiorato, A. E., and Corley, W. G. (1980). "Tension lap splices under severe load reversals." 7th World Conf. on Earthquake Engineering, Kelaynak Printing Company, Ankara, Turkey, 1-5.

Bimschas, M. (2010). "Displacement based seismic assessment of existing bridges in regions of moderate seismicity." Ph.D. thesis, ETH Zurich, Zürich, Switzerland.

Birely, A. (2012). "Seismic performance of slender reinforced structural concrete walls." Ph.D. thesis, Univ. of Washington, Washington, DC.

Biskinis, D., and Fardis, M. N. (2010a). "Deformations at flexural yielding of members with continuous or lap spliced bars." Struct. Concr., 11(3), $127-138$.

Biskinis, D., and Fardis, M. N. (2010b). "Flexure-controlled ultimate deformations of members with continuous or lap-spliced bars." Struct. Concr., 11(2), 93-108.

Calabrese, A., Almeida, J. P., and Pinho, R. (2010). "Numerical issues in distributed inelasticity modeling of RC frame elements for seismic analysis." J. Earthquake Eng., 14(S1), 38-68.

Canbay, E., and Frosch, R. J. (2005). "Bond strength of lap-spliced bars." ACI Struct. J., 102(4), 605-614.

Chai, Y., Priestley, M., and Seible, F. (1991). "Seismic retrofit of circular bridge columns for enhanced flexural performance." ACI Struct. J., 88(5), 572-584.

Chinn, J., Ferguson, P. M., and Thompson, J. N. (1955). "Lapped splices in reinforced concrete beams." ACI J., 52(10), 201-213.

EERI (Earthquake Engineering Research Institute). (1995). "Buildings (EERI reconnaissance report Guam)." Earthquake Spectra, 11(S3), 63-137.

EERI-GEER (Earthquake Engineering Research Institute-Geo-Engineering Earthquake Reconnaissance). (2007). "Preliminary observations on the Niigata-Chuetsu Oki, Japan, earthquake of July 16, 2007." EERI Special Earthquake Rep, Oakland, CA.

Eligehausen, R., Popov, E. P., and Bertero, V. V. (1983). "Local bond stressslip relationships of deformed bars under generalized excitations." Rep. UCB/EERC-83/23, Univ. of California, Berkeley, CA.

Elnady, E. M. M. (2008). "Seismic rehabilitation of RC structural walls." Ph.D. thesis, McMaster Univ., Hamilton, ON, Canada.

European Committee for Standardization. (2004). "Eurocode 2: Design of concrete structures. Part 1-1: General rules and rules for buildings." EN 1992-Part 1-1, Brussels, Belgium.

Fagundo, F. (1979). "Behavior of lapped splices in R.C. beams subjected to cyclic loads." Ph.D. thesis, Cornell Univ., Ithaca, NY.

Ferguson, P. M., and Briceno, E. A. (1969). "Tensile lap splices. Part I: Retaining wall type, varying moment zone." Research Rep. No. 113-2, Texas Highway Dept., Austin, TX.

Ferguson, P. M., and Krishnaswamy, C. N. (1971). "Tensile lap splices. Part II: Design recommendations for retaining wall, Splices and large bar splices." The Texas Highway Department in cooperation with the U.S. Department of Transportation, Rep. 113-2 Cont., Federal Highway Administration, Bureau of Public Roads, Washington, DC. 
Gergely, P., Fagundo, F., and White, R. N. (1979). "Bond and splices in reinforced concrete for seismic loading." CEB Bulletin d'Information No. 132, AICAP-CEB Symp., Rome.

Hannewald, P. (2013). "Seismic behavior of poorly detailed RC bridge piers." Ph.D. thesis, École Polytechnique Fédérale de Lausanne, Lausanne, Switzerland.

Hannewald, P., Bimschas, M., and Dazio, A. (2013). "Quasi-static cyclic tests on RC bridge piers with detailing deficiencies." Institut fur Baustatik und Konstruktion, Bericht Nr. 352, ETH Zurich, Zürich, Switzerland.

Hardisty, J. N., Villalobos, E., Richter, B. P., and Pujol, S. (2015). "Lap splices in unconfined boundary elements." Concr. Int., 37(1), 51-58.

Hester, C. J., Salamizavaregh, S., Darwin, D., and McCabe, S. L. (1993). "Bond of epoxy-coated reinforcement: Splices." ACI Struct. J., 90(1), 89-102.

Kilic, S. A., and Sozen, M. A. (2003). "Evaluation of effect of August 17, 1999, Marmara earthquake on two tall reinforced concrete chimneys." ACI Struct. J., 100(3), 357-364.

Kim, S., and Shiohara, H. (2012). "Dynamic response analysis of a tall RC chimney damaged during 2007 Niigata-ken Chuetsu-Oki earthquake." 15th World Conf. on Earthquake Engineering, Lisbon, Portugal.

Layssi, H., and Mitchell, D. (2012). "Experiments on seismic retrofit and repair of reinforced concrete shear walls." Proc., 6th Int. Conf. FRP Composites in Civil Engineering-CICE, Rome, 1-8.

Lowes, L. N., Lehman, D. E., Birely, A. C., Kuchma, D. A., Marley, K. P., and Hart, C. R. (2012). "Earthquake response of slender planar concrete walls with modern detailing." Eng. Struct., 43, 31-47.

Lukose, K., Gergely, P., and White, R. (1982). "Behavior of reinforced concrete lapped splices for inelastic cyclic loading." ACI J. Proc., 79(5), $355-365$.

Lynn, A. C., Moehle, J. P., Mahin, S. A., and Holmes, W. T. (1996). "Seismic evaluation of existing reinforced concrete building columns." Earthquake Spectra, 12(4), 715-739.

Melek, M., and Wallace, J. W. (2004). "Cyclic behavior of columns with short lap splices." ACI Struct. J., 101(6), 802-811.

Melek, M., Wallace, J. W., and Conte, J. P. (2003). "Experimental assessment of columns with short lap splices subjected to cyclic loads." PEER Rep. 2003/04, Pacific Earthquake Engineering Research Center, Richmond, CA.

Muhlenbruch, C. W. (1948). "The effect of repeated loading on the bond strength of testing materials." ASTM Proc., 48, 977-985.

Orangun, C. O., Jirsa, J. O., and Breen, J. E. (1977). "A reevaluation of test data on development length and splices." ACI J., 74(3), 114-122.

Pam, H. J., and Ho, J. C. M. (2010). "Effects of steel lap splice locations on strength and ductility of reinforced concrete columns." Adv. Struct. Eng., 13(1), 199-214.

Panahshahi, N., White, R. N., and Gergely, P. (1992). "Reinforced concrete compression lap splices under inelastic cyclic loading." ACI Struct. J., 89(2), 164-175.

Paterson, J., and Mitchell, D. (2003). "Seismic retrofit of shear walls with headed bars and carbon fiber wrap." J. Struct. Eng., 10.1061/(ASCE) 0733-9445(2003)129:5(606), 606-614.

Paulay, T. (1982). "Lapped splices in earthquake-resisting columns." ACI J., 79(6), 458-469.
Priestley, M. J. N., Calvi, G. M., and Kowalsky, M. J. (2007). Displacement-based seismic design of structures, IUSS Press, Pavia, Italy.

Priestley, M. J. N., Seible, F., and Calvi, G. M. (1996). Seismic design and retrofit of bridges, Wiley, New York.

Rezansoff, T., Zacaruk, J. A., and Topping, R. (1988). "Tensile lap splices in reinforced concrete beams under inelastic cyclic loading." ACI Struct. $J ., 85(1), 46-52$.

Seliem, H. M., et al. (2009). "Bond characteristics of ASTM A1035 steel reinforcing bars." ACI Struct. J., 106(4), 530-539.

SIA (Swiss Society of Engineers and Architects). (2004). "Concrete structures." SIA 262, Swiss Standards Association, Zurich, Switzerland.

Sivakumar, B., Gergely, P., and White, R. N. (1983). "Suggestions for the design of R/C lapped splices for seismic loading." Concr. Int., 5(2), $46-50$.

Song, C., Pujol, S., and Lepage, A. (2012). "The collapse of the Alto Río building during the 27 February 2010 Maule, Chile, earthquake." Earthquake Spectra, 28(Suppl.1), S301-S334.

Sparling, B., and Rezansoff, T. (1986). "The effect of confinement on lap splices in reversed cyclic loading." Can. J. Civil Eng., 13(6), 681-692.

Sritharan, S., Beyer, K., Henry, R. S., Chai, Y. H., Kowalsky, M., and Bull, D. (2014). "Understanding poor seismic performance of concrete walls and design implications." Earthquake Spectra, 30(1), 307-334.

Standards New Zealand. (2006). "Concrete structures standard. Part 1The design of concrete structures." NZS 3101-Part 1, Wellington, New Zealand.

Tarquini, D., Almeida, J. P., and Beyer, K. (2015). "Database on 16 reinforced concrete walls with lap splices and 8 reference units with continuous reinforcement." <www.zenodo.org> (Jul. 2, 2015).

Tarquini, D., Almeida, J. P., and Beyer, K. (2017). "Influence of lap-splices on the cyclic inelastic response of reinforced concrete walls. II: Shell element simulation with new equivalent uniaxial steel model." J. Struct. Eng., 04017157.

Tepfers, R. (1979). "Cracking of concrete cover along anchored deformed reinforcing bars." Mag. Concr. Res., 31(106), 3-12.

Tocci, A. D., Gergely, P., and White, R. N. (1981). "The behavior and strength of lapped splices in $\mathrm{R} / \mathrm{C}$ beams subjected to repeated loads." Rep. No. 81-1, Dept. of Structural Engineering, Cornell Univ., Ithaca, NY.

Valluvan, R., Kreger, M. E., and Jirsa, J. O. (1993). "Strengthening of column splices for seismic retrofit of nonductile reinforced concrete frames." ACI Struct. J., 90(4), 432-440.

Villalobos, E., Escolano-Margarit, D., Ramìrez-Màrquez, A. L., and Pujol, S. (2017). "Seismic response of reinforced concrete walls with lap splices." Bull. Earthquake Eng., 15(5), 2079-2100.

Villalobos, E. J. F. (2014). "Seismic response of structural walls with geometric and reinforcement discontinuities." Ph.D. thesis, Purdue Univ., West Lafayette, IN.

Zuo, J., and Darwin, D. (2000). "Splice strength of conventional and high relative rib area bars in normal and high-strength concrete." ACI Struct. J., 97(4), 630-641. 